\title{
The polymorphic nature of the human dopamine D4 receptor gene: A comparative analysis of known variants and a novel 27 bp deletion in the promoter region
}

\author{
E Szantai ${ }^{\dagger 1,2}$, R Szmola ${ }^{\dagger 1}$, M Sasvari-Szekely ${ }^{1}$, A Guttman ${ }^{3}$ and Z Ronai*1
}

Address: ${ }^{1}$ Department of Medical Chemistry, Molecular Biology and Pathobiochemistry, Semmelweis University, Budapest, Hungary, ${ }^{2}$ Department of Genetics, Eotvos Lorand University, Budapest, Hungary and ${ }^{3}$ Marie Curie Chair of the EC, Horvath Lab. of Bioseparation Science, Institute of Analytical Chemistry and Radiochemistry, Leopold-Franzens University Innsbruck, Austria

Email: E Szantai - szantai@puskin.sote.hu; R Szmola - szmola1@freemail.hu; M Sasvari-Szekely - sas@puskin.sote.hu; A Guttman - Andras.Guttman@uibk.ac.at; Z Ronai* - ronai@puskin.sote.hu

* Corresponding author †Equal contributors

Published: 28 June 2005

BMC Genetics 2005, 6:39 doi:10.1/86/147|-2156-6-39
Received: 14 February 2005

Accepted: 28 June 2005

This article is available from: http://www.biomedcentral.com/I47I-2156/6/39

(c) 2005 Szantai et al; licensee BioMed Central Ltd.

This is an Open Access article distributed under the terms of the Creative Commons Attribution License (http://creativecommons.org/licenses/by/2.0), which permits unrestricted use, distribution, and reproduction in any medium, provided the original work is properly cited.

\begin{abstract}
Background: The human dopamine D4 receptor (DRD4) is a candidate gene of great interest in molecular studies of human personality and psychiatric disorders. This gene is unique in having an exceptionally high amount of polymorphic sites both in the coding and in the promoter region.

Results: We report the identification of a new 27 bp deletion starting 524 bp upstream of the initiation codon (27 bp del) of the dopamine D4 receptor (DRD4) gene, in the close vicinity of the -52 IC $>$ T SNP. The presence of the 27 bp deletion leads to the misgenotyping of the $-6 \mid 6 C>G$ SNP by the Sau96 I RFLP method, thus the genotype determination of the mutation is of additional importance. The frequency of this novel sequence variation is considerably low (allele frequency is $=0.16 \%$ ), as no homozygotes, and only 3 heterozygote carriers were found in a healthy, unrelated Caucasian sample $(N=955)$.

Conclusion: Remarkably, the deleted region contains consensus sequences of binding sites for several known transcription factors, suggesting that the different alleles may affect the transcriptional regulation of the gene. A comparison of methods and results for the allelic variations of the DRD4 gene in various ethnic groups is also discussed, which has a high impact in psychiatric genetic studies.
\end{abstract}

\section{Background}

The dopaminergic system has received a significant amount of attention due to the important role it plays in the central nervous system in motor control, cognition, reward, emotion and endocrine regulation [1]. Recently, the D4 dopamine receptor (DRD4) gene [GenBank:U95122, GenBank:L12397] has been the target of psychogenetic studies mainly because it possesses a high number of polymorphisms [2], presumably as a conse- quence of its subtelomeric chromosomal localization (11p15.5) [3,4]. Polymorphisms in the DRD4 gene have received particular attention in the past decade because of their possible role in mental disorders [5-8], substance abuse [9-11] and the normal variations of human personality [12-16].

The gene and its regulatory region contain several length variations and numerous single nucleotide 


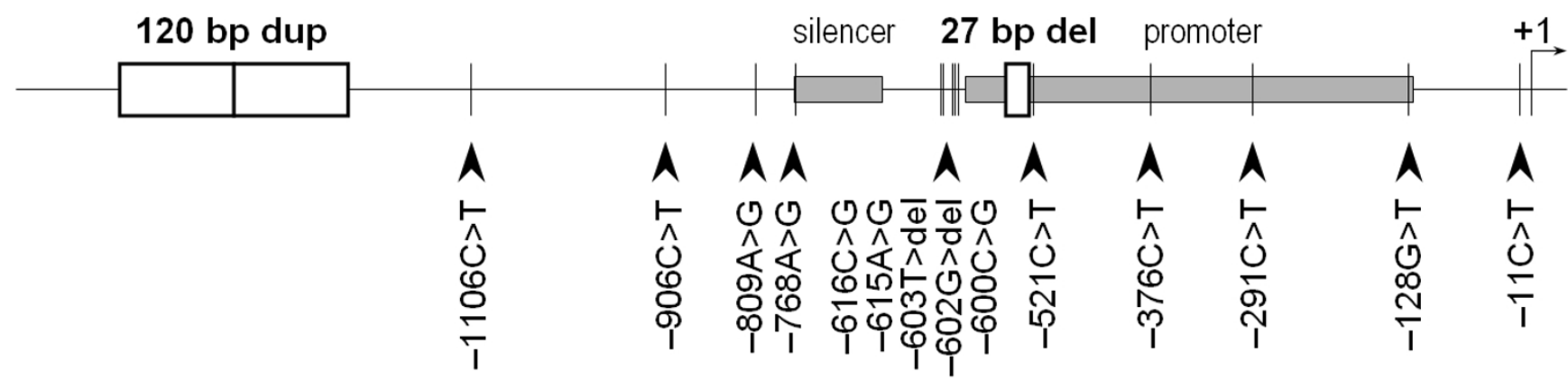

\section{Figure 4}

Location of the $\mathbf{2 7}$ bp deletion and other polymorphic sites in the promoter region of the human DRD4 gene. The deleted region starts 524 bp upstream of the initiation codon. Figure is drawn to scale and each position is shown relative to the first nucleotide of the initiation codon indicated as $+I$. A cell type-specific promoter region between -591 and -123 contains the promoter of the gene, and the negative modulator is between the -770 and -679 positions (grey boxes). Open boxes indicate length variants at the DRD4 promoter region. Arrowheads specify the positions of SNPs.

polymorphisms (SNPs). Much interest has been focused on these sequence variants in the investigation of complex neurobehavioral disorders using association study methods.

However, results of the psychogenetic association studies are often controversial. There are several reasons for the lack of conclusive results, such as the dangers of population stratification and the small effect size of individual genes complicated by oligogenic interactions [17]. Failure to confirm associations determined by various laboratories is partially explained by differences in demographic and ethnic structure of the subsequent studies, as a consequence of the diversity in allele frequencies of several polymorphisms among different populations. Moreover, differences in phenotyping and genotyping methodology may also obscure the weak effect of a gene variant on the investigated trait.

The human dopamine $\mathrm{D} 4$ receptor gene, located proximal to the Harvey-RAS oncogene locus and distal to the tyrosine hydroxylase locus [18], consists of 4 exons. The third exon contains a polymorphic 48 bp repeat region, the repeat number varies between 2 and 11 . This part of the gene encodes the putative third cytoplasmic loop, and thus the polymorphism changes the length of the receptor protein [19]. Given that the variable number of $48 \mathrm{bp}$ repeat (VNTR) is in a region that couples to G proteins and mediates postsynaptic effects [20], association studies have generated considerable interest. The DRD4 VNTR has been widely studied since a striking association was described between the seven-repeat allele and the human personality trait of increased novelty seeking $[12,13]$, although the replications of the initial findings have been controversial $[9,21]$. So far evidence suggests that there is an association between the DRD4 7 repeat allele and attention deficit hyperactivity disorder (ADHD) also, although the effect size is small [6].

Further polymorphisms of the coding region of the DRD4 gene were also identified, [5,22-24], moreover additional mutations and polymorphisms have been described just recently in the introns as well [25-27].

Analysis of the 5' upstream region of DRD4 gene revealed that the promoter region is probably located in the region between -591 and -123 relative to the initiation codon, with a negative modulator between the -770 and -679 positions [28]. This region of the DRD4 gene is also astonishingly abundant in polymorphisms (see Fig. 4), including numerous SNPs [29,30], and a 120 bp tandem duplication [31].

The $-521 \mathrm{C}>\mathrm{T}$ SNP is located on a CpG island at one end of a cell-type specific regulatory element [28]. The -521C allele was shown to be $40 \%$ more active than the T allele in an in vitro transient expression system [32]. Moreover, a significantly higher incidence of the CC genotype was found among schizophrenics [32]. The SNP has also been associated with novelty seeking behavior in separate studies of Japanese, Caucasian and Afro-American samples $[16,33,34]$, but negative results were also described [3537]. Meta-analyses of existing studies have been conducted to provide statistical measures of the small association between -521 C>T SNP genotypes and novelty seeking [38]. 
A regularly investigated polymorphism in the promoter sequence of the DRD4 gene is the $-616 \mathrm{C}>\mathrm{G}$ SNP that may result in the gain of an AP-2 transcription factor binding site [39] and thereby affects the expression characteristics of the receptor. Associations of the $-616 \mathrm{C}>\mathrm{G}$ SNP with ADHD [39,40], schizophrenia [41] and personality dimensions [33] were studied but did not yield consequent results. Barr et al.[39] added the $-616 \mathrm{C}>\mathrm{G}$ SNP to the investigations of the 5' upstream region by studying the haplotype transmissions of three polymorphisms in the promoter region and the $48 \mathrm{bp}$ VNTR in exon III as genetic risk factors for ADHD. An association between ADHD and the $-616 \mathrm{C}>\mathrm{G}$ SNP was reinforced recently [40].

An additional length polymorphism of the 5 ' untranslated region of the DRD4 gene has been reported as common in the population. The polymorphism consists of a $120 \mathrm{bp}$ tandem duplication $1.2 \mathrm{~kb}$ upstream from the initiation codon [31] and gives rise to the Pst I RFLP previously reported [42]. Association studies between the $120 \mathrm{bp}$ duplication and the occurrence of ADHD hypothesized the potential significance of this region in the regulation of transcription [43]. Experimental evidence suggests enhanced binding capacity of Sp1 transcription element to the duplicated form [44]. The duplication is abundant in the human race, although allele frequencies do vary among different ethnic groups (see Discussion).

Identification of new, perhaps functional length variants is especially intriguing because the up-regulation of D4 receptors may be more significant than any changes in the protein structure $[45,46]$. In previous publications the density of DRD4 was found to be six fold elevated in the brains of schizophrenic patients [47], and the DRD4 mRNA was elevated in the frontal cortex of schizophrenics in post mortem studies in comparison with controls [47], pointing to possible allelic variants that influence the transcription levels of the DRD4 gene. The $-521 \mathrm{C}>\mathrm{T}$ SNP has been shown to affect transcriptional activity in an in vitro transient expression system [32]. In the present study we characterized a new deletion mutation in the promoter region of the DRD4 gene, which is a promising target of future association studies. This sequence variation has been discovered during the large-scale application of our recently published Sau96 I RFLP genotyping method of the $-616 \mathrm{C}>\mathrm{G}$ SNP [30]. A novel technique was developed for the screening of this mutation, and applied on a Caucasian (Hungarian) population of 959 individuals.

\section{Results}

Recently, we described a novel genotyping method for the analysis of the $-616 \mathrm{C}>\mathrm{G}$ SNP in the DRD4 gene [GenBank:L12397] promoter region [GenBank:U95122], consisting of the Sau96 I RFLP and an allele specific amplification procedure. The parallel application of the two independent methods (referred to as double genotyping) highly increases the reliability of the study, especially when investigating outstandingly polymorphic regions such as the DRD4 gene [30]. During the large-scale genotyping of the -616C>G SNP by this newly described double-genotyping method, we noticed some abnormalities in the size of the produced fragments. Fig. (1) unmistakably shows the two different size fragments obtained from the Sau96 I RFLP where the 207 bp long fragment represents the $-616 \mathrm{C}$ allele and the $172 \mathrm{bp}$ long product refers to the cleaved $-616 \mathrm{G}$ allele. Surprisingly, in lane 5, an unexpected short fragment was produced (indicated by an asterisk) in case of a sample having a -616 GG genotype determined by allele-specific PCR [30] (not shown). The size of the indefinite fragment was approximately $30 \mathrm{bp}$ less than that of the expected $172 \mathrm{bp}$ long PCR product of the $-616 \mathrm{G}$ allele. The appearance of the unusual PCR fragment has two feasible explanations: (1) There might be a new SNP in the amplified fragments of the sample resulting in an additional polymorphic Sau96 I restriction site, (2) or a length variation in one of the alleles of the individual might also be responsible for the production of the short fragment. Electrophoretic analysis of the undigested PCR-products yielded two distinct bands demonstrating that the new sequence variant was a deletion.

When investigating the sample containing the deletion by allele-specific amplification no abnormalities were found (not shown). This can be readily explained focusing on the setup of this method, which applies a sense C-specific and an antisense G-specific primer for the simultaneous amplification of two PCR-products with different length corresponding to the two alleles respectively. Consequently, if the new sequence variant is localized upstream from the -616C>G SNP on the same chromosome as the $616 \mathrm{C}$ allele or downstream from the SNP together with the $\mathrm{G}$ allele, then the deleted region is not amplified thus the mutation does not show up on the electropherogram. To confirm our notion we carried out the allele-specific PCR of this sample applying primers with opposite orientation (i.e. a sense $\mathrm{G}$-and an antisense $\mathrm{C}$-specific primer). In this arrangement we detected a shortened $-616 \mathrm{G}$ specific PCR product, suggesting that the deletion is localized downstream from the $-616 \mathrm{C}>\mathrm{G}$ SNP composing a haplotype with $-616 \mathrm{G}$ variant in this sample. Moreover, it is important to note that the deletion does not cause any uncertainty if the genotyping of the $-616 \mathrm{C}>\mathrm{G}$ SNP is carried out by allele specific amplification, as the size difference between the two allele-specific products is fairly big (252 bp) excluding the possibility of misgenotyping.

Sequencing of the shortened fragment of the Sau96 I RFLP (referred to as the product of the "Del" allele) also confirmed the presence of the deletion in this sample. Fig. (2) 


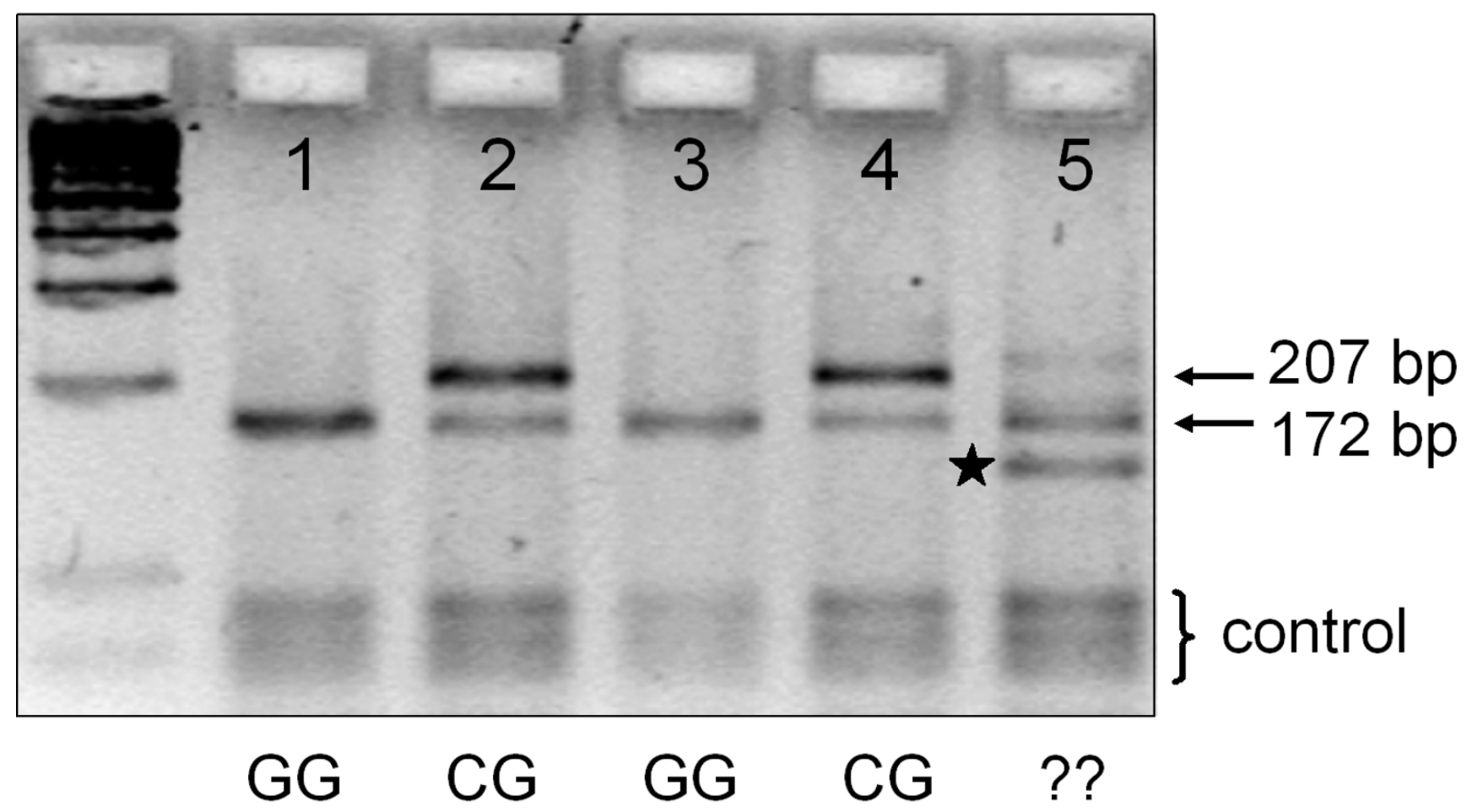

Figure I

Sau96 I RFLP genotyping method of the -6 I 6C>G SNP reveals a new variation in the DRD4 gene. Representative genotyping results are depicted. Conditions of PCR amplification and electrophoretic separation were carried out as previously described (see Figure 2. in [30]). The asterisk indicates the short PCR fragment containing the deletion.

shows a sequence containing the deletion aligned to that obtained from the GeneBank http:// www.ncbi.nlm.nih.gov: "Human dopamine D4 receptor gene, 5' flanking region" (accession number: U95122) and "Homo sapiens Dopamine D4 receptor (DRD4) gene" (accession number: L12397). It is unambiguous that the deletion affects 27 base-pairs, however its position cannot be marked explicitly since it is located between two GGAG sequences and it is hard to agree on which GGAG is enclosed by the deleted section. Therefore the mutation can be placed anywhere between the $-524^{\text {th }}$ and the $-554^{\text {th }}$ positions relative to the initiation codon. According to the nomenclature of the Human Genome Variation Society http://www.hgvs.org/mutnomen/ we suggest the -524 position to be the assigned start point of the deletion, since this is the closest point to the coding sequence of the DRD4 gene.

PCR primers flanking the region of the mutation were designed (see "Methods") to determine the genotype of the 27 bp deletion in our population of unrelated Caucasians. Fig. (3) shows the electrophoretic separation of the obtained PCR amplicons in the analysis of 5 samples. A longer 391 bp (designated "Non-del") and a shorter 364 bp (referred to as "Del") fragment was formed in lane 3 representing a heterozygote for the 27 bp deletion ("Del"/ "Non-del"). The rest of the individuals (lanes 1, 2, 4 and 5) do not contain the deletion: only the longer fragment was formed showing a homozygote "Non-del" / "Non-del" genotype. In order to determine the allele frequency of this new sequence variation, we screened for the Del allele in a large $(N=955)$ healthy, unrelated Hungarian (Caucasian) population. Seeing that our results show a very low allele frequency of $0.16 \%$ for the Del allele of the DRD4 promoter region, this new variant can be considered as a mutation rather than a polymorphism. The Mendelian inheritance of the novel 27 bp deletion was also investigated by a three-generation family analysis, where one heterozygote was found in the first and one in the second generation, respectively. We did not find any homozygotes in our sample population, or among the available relatives $(N=4)$ of the heterozygote individuals.

To assign the functional role of the 27 bp deletion we carried out an "in silico" transcription factor binding analysis. The Transcription Element Search System (TESS; http:// 


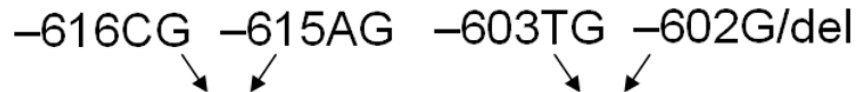
GGGGGCTGAGGACCAGAGGCTGCTGGGGGGGGGCGGCGGGATGAGCTAGGCGTCGGCGGT : : : : : : : : : : : : : : : : : : : : : : : : : : : : : : : : : : : : : : : : : : : : : : : : : : : GGGGGCTGAGGACCAGAGGCTGCT-GGGGGGGGCGGCGGGATGAGCTAGGCGTCGGCGGT

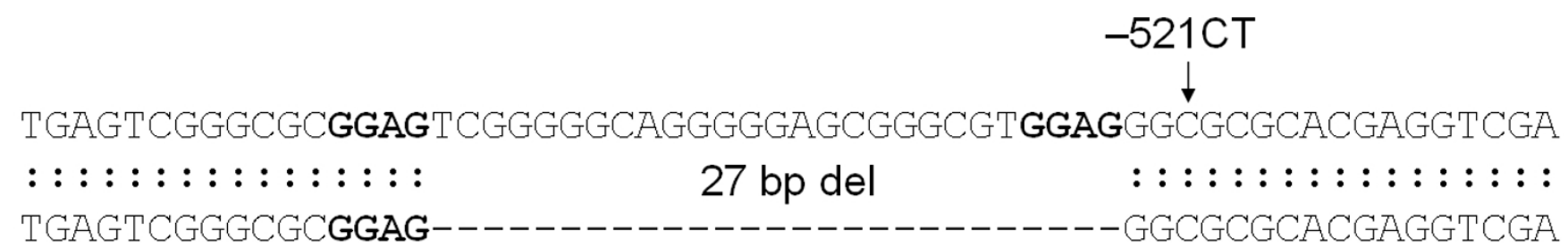

GGCGAGTCCGCGGGGGAGGCGGGCAGAGCCTGAGCTCAGGTCTTTCTGCGTCTGGCGGAA

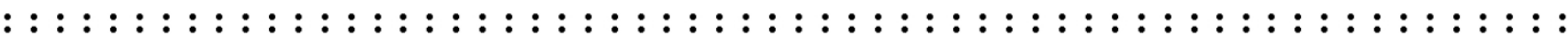
GGCGAGTCCGCGGGGGAGGCGGGCAGAGCCTGAGCTCAGGTCTTTCTGCGTCTGGCGGAA

Figure 2

Alignment of the deleted allele string with the published DNA sequence of the upstream region [GenBank:U95 I 22, GenBank:LI 2397.] Positions of the -6I6C>G, -6I5A>G, -603T>G, -602G>del and $-52 \mid C>T$ SNPs are specified. The bold letters indicate the ambiguous localization of the deletion, however according to the nomenclature of the Human Genome Variation Society the suggested start point is the -524 position.

www.cbil.upenn.edu/tess/) was used to specify the transcription factors that can play a role in the gene expression regulation by binding to this region. Even when applying stringent search parameters ( 6 bases as "Minimum string length" and allowing no mismatch in the sequence) the following human transcription factors were suggested to bind the region of investigation: NF-E2, AP-2, Sp1. Although the physiological importance of this result needs to be further studied, the presence of the Sp1 site is especially notable, as a zinc finger type transcription factor (dopamine receptor regulating factor, DRRF) was described to effectively bind to the same sequences as Sp1 in the dopamine receptor promoters [48].

\section{Discussion}

Here we described a novel 27 bp deletion in the DRD4 promoter region, which has several important aspects. Primarily, it is a source of misgenotyping of the $-616 \mathrm{C}>\mathrm{G}$ SNP when using the standard genotyping method of Sau96 I RFLP. As this SNP is often studied in psychiatric genetics finding the appropriate genotyping methodology is of great importance $[39,40]$. The problem arises from the hardly detectable difference between the $180 \mathrm{bp}$ amplicon of the $27 \mathrm{bp}$ Del and the $-616 \mathrm{C}$ allele-combination (i.e. haplotype) vs. the $172 \mathrm{bp}$ product of the $-616 \mathrm{G}$ variant after Sau96 I digestion. Thus, the existence of such a deletion is a source of error, since some of the $-616 \mathrm{C}$ alleles might be misgenotyped as $-616 \mathrm{G}$ in the presence of the deletion.

On the other hand, using the previously reported [30] allele-specific amplification, it is possible to distinguish between the $-616 \mathrm{C}$ and $\mathrm{G}$ alleles with no doubt, even in the presence of the deletion. We can explain the results assuming that the four samples heterozygous for the deletion contained the deleted allele on the same chromosome as the $-616 \mathrm{G}$ allele. This assumption was later confirmed by allele specific sequencing. As the -616C-specific primer was the sense and the $-616 \mathrm{G}$-specific primer was the antisense primer in our system, the obtained products did not contain the region of the deletion. When applying a -616 G-specific sense primer in another setup of allele specific amplification, the G-specific fragment clearly showed the presence of the 27 bp deletion (data 


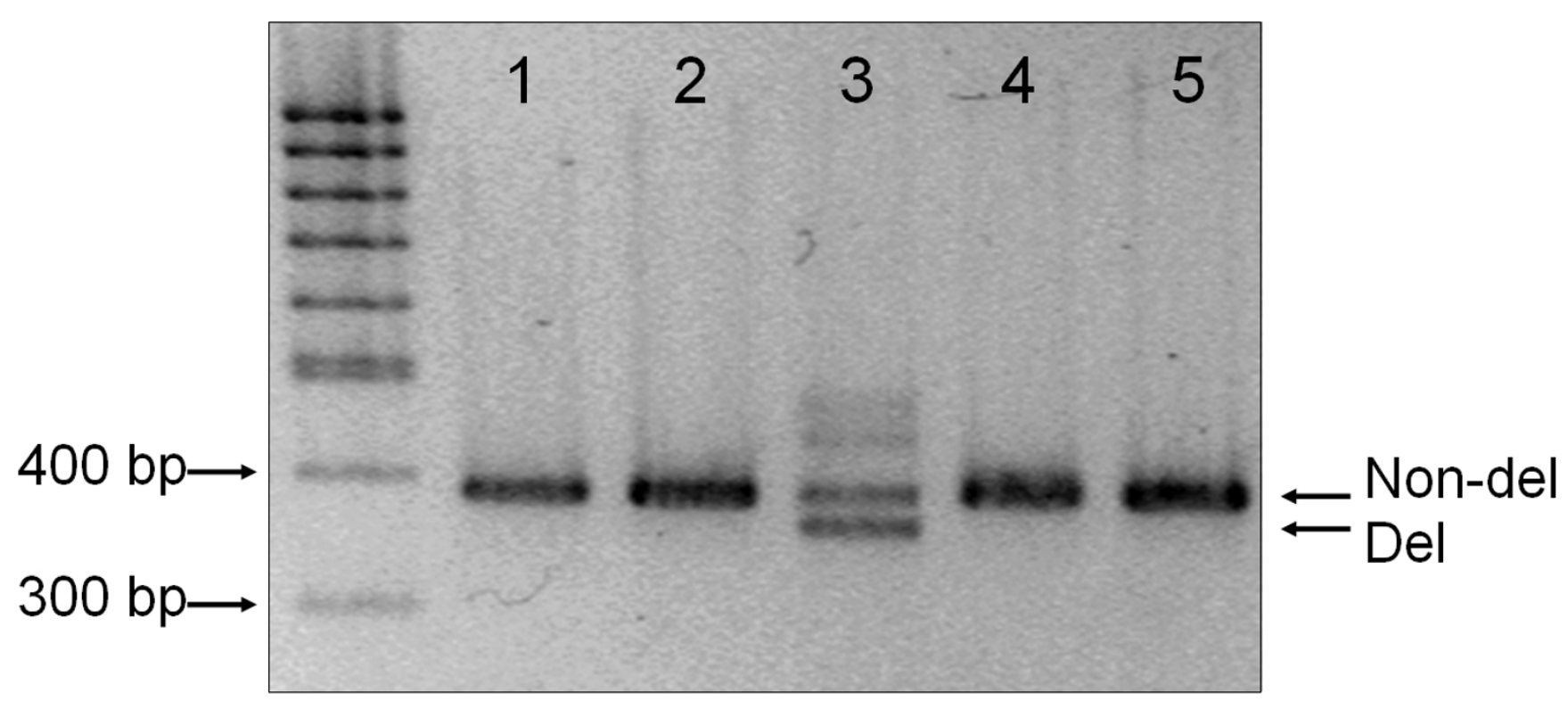

\section{Figure 3}

Genotyping the $\mathbf{2 7}$ bp deletion mutation in healthy Hungarian individuals. Amplification conditions: reaction mixtures contained $200 \mu \mathrm{M}$ dATP, dCTP, dTTP, and $100 \mu \mathrm{M}$ dGTP and dITP; I $\mu$ M of each primer (see Methods), I ng DNA template, $0.25 \cup$ DNA polymerase, Ix reaction buffer, and Ix Q solution in a total volume of $10 \mu \mathrm{L}$. Thermocycling conditions: $95^{\circ} \mathrm{C}$ for $15 \mathrm{~min}$, followed by 35 cycles of $94^{\circ} \mathrm{C}$ for I min; $65^{\circ} \mathrm{C}$ for $30 \mathrm{sec} ; 72^{\circ} \mathrm{C}$ for I min, finished by $72^{\circ} \mathrm{C}$ for $10 \mathrm{~min}$. Electrophoresis: fine resolution agarose gel in $40 \mathrm{mM}$ Tris, $10 \mathrm{mM}$ EDTA pH 8.0 buffer solution at room temperature, $6.6 \mathrm{~V} / \mathrm{cm}$ electric field, $90 \mathrm{~min}$, followed by I $\mu \mathrm{g} / \mathrm{mL}$ ethidium bromide staining. The faint diffuse bands in lane 3 migrating slower than the representative fragments presumably contain heteroduplex molecules.

not shown), but the length variation did not influence the accuracy of the $-616 \mathrm{C}>\mathrm{G}$ SNP genotyping after all.

Although the occurrence of the 27 bp deletion is rather low $(0.16 \%)$ in our healthy Caucasian population, the allele frequency might be different in other ethnic groups and various clinical samples. Therefore, further studies are necessary to gather information on the allele and genotype frequencies of this novel length variant in a range of other populations, and these results should be considered in the psychogenetic association studies of the $-616 \mathrm{C}>\mathrm{G}$ polymorphism as well.

It is of additional importance to perform association studies in different populations since each may represent distinct environments that could possibly interact with genetic variants. The methodological conditions and demographic setting is crucial in evaluating the strength of a relationship and in replicating an association found by different investigations. Here we address the differences in ethnic structure and methodological approach used in the successive studies of commonly investigated DRD4 gene variations and review the diversity of their allele frequencies in different populations around the globe.

The variable number of a 48 bp repeat ( 48 bp VNTR) in exon III makes the DRD4 gene one of the most frequently studied genes in psychiatric genetics. The "long form" (7R) of this length polymorphism was found to be associated with the personality trait of "novelty seeking" $[12,13]$, children's attention deficit hyperactivity syndrome [8] and drug abuse [10]. In the Hungarian population (as well as in other Caucasian samples) the 4 repeat allele occurs most frequently $(65.0 \%)$, followed by the 7 repeat $(19.5 \%)$ and the 2 repeat $(8,9 \%)$ variations. The rare alleles include the 3 repeat $(3.8 \%), 8$ repeat $(1.2 \%), 5$ repeat $(1.1 \%)$ and the 6 repeat $(0.4 \%)$ variants, whereas no 9 and 11 repeat allele was found (see Table 1 ). We have identified one 10 repeat allele $(0.1 \%)$ in our large $(2 \mathrm{~N}=$ 1196) Caucasian sample. This form has only been reported previously in the African population with $1 \%$ incidence [49]. In numerous studies, genotype groups were defined only by absence vs presence of the DRD4 exon III 7 repeat, these results are not included in the table. 
Table I: Allele frequency data for the $48 \mathrm{bp}$ VNTR polymorphism of DRD4

\begin{tabular}{|c|c|c|c|c|c|c|c|c|c|c|}
\hline \multicolumn{2}{|r|}{ Origin of populations } & \multicolumn{9}{|c|}{ Allele frequency (\%) } \\
\hline & & $2 \mathbf{N}$ & 2 & 3 & 4 & 5 & 6 & 7 & 8 & 10 \\
\hline \multirow[t]{9}{*}{ Caucasian } & Hungarian (Ronai et al., 2000) & 1196 & 8.9 & 3.8 & 65.0 & 1.1 & 0.4 & 19.5 & 1.2 & 0.1 \\
\hline & European-mixed (Chang et al., 1996) & 176 & 12.0 & 6.0 & 57.0 & 2.0 & 1.0 & 21.0 & 1.0 & 0.0 \\
\hline & Caucasians in New Zealand (Mill et al., 2002) & 1760 & 8.8 & 4.6 & 65.0 & 0.9 & 0.6 & 19.4 & 0.6 & 0.0 \\
\hline & German (Strobel et al., 2003) & 230 & 7.3 & 4.3 & 66.5 & 0.9 & 0.4 & 19.1 & 1.3 & 0.0 \\
\hline & German (Franke et al., 2000) & 394 & 7.1 & 3.3 & 70.1 & 3.3 & 0.5 & 15.2 & 0.5 & 0.0 \\
\hline & Italian (Mochi et al., 2003) & 212 & 10.4 & 3.3 & 68.9 & 2.8 & 0.9 & 13.2 & 0.5 & 0.0 \\
\hline & Italian (DeLuca et al., 2003) & 190 & 11.0 & 5.3 & 67.9 & 0.5 & 0.5 & 13.7 & 1.0 & 0.0 \\
\hline & Mean & & 8.9 & 4.3 & 65.6 & 1.3 & 0.5 & 18.5 & 0.8 & 0.0 \\
\hline & Standard deviation & & 1.1 & 0.6 & 2.5 & 0.8 & 0.2 & 2.1 & 0.3 & 0.0 \\
\hline \multirow[t]{4}{*}{ Asian } & Chinese (Li et al., 2000) & 608 & 18.8 & 1.2 & 76.6 & 1.3 & 2.1 & 0.0 & 0.0 & 0.0 \\
\hline & Japanese (Ishiguro et al., 2000) & 680 & 12.0 & 1.0 & 81.0 & 4.0 & 1.0 & 1.0 & 0.0 & 0.0 \\
\hline & Mean & & 15.2 & I.I & 78.9 & 2.7 & 1.5 & 0.5 & 0.0 & 0.0 \\
\hline & Standard deviation & & 3.4 & 0.1 & 2.2 & 1.3 & 0.5 & 0.5 & 0.0 & 0.0 \\
\hline African & Falashan (Chang et al., 1996) & 128 & 3.0 & 0.0 & 83.0 & 0.0 & 2.0 & 11.0 & 0.0 & 1.0 \\
\hline American & Mayans (Chang et al., 1996) & 100 & 1.0 & 0.0 & 57.0 & 0.0 & 3.0 & 39.0 & 0.0 & 0.0 \\
\hline
\end{tabular}

The prevalence of the most common alleles in the Hungarian population studied matches the frequencies measured by Mill et al. (New Zeland [50]) and Strobel et al. (Germany [51]). Minor differences of the 7 repeat frequencies incidence among Caucasians might originate from population stratification. If, however, allele frequencies of similar populations are quite different this problem might also originate from preferential amplification of shorter PCR products [52] as a methodological artifact in this highly GC rich region, resulting in an underestimation of the 7 repeat allele frequencies in the above populations.

Noticeably, there is considerable variation in the distribution of the alleles as we compare Caucasian and Asian populations. The occurrence of the 7 repeat allele is extremely low $(0.5 \%)$ in Chinese and Japanese samples, and relatively high in North American Mayans (39\%), whereas Caucasians have an intermediate $(18.5 \%)$ mean prevalence. There are two theories describing the origin of the 7 repeat allele $[53,54]$, however independently on the reason for the varying frequency data of this variation, a high danger of artifacts caused by population admixture should definitely be taken into account when genetic association studies are being performed [55].

Beside the length polymorphism of the DRD4 gene coding sequence, the $5^{\prime}$ upstream region of this gene has numerous sequence variations also. Among the promoter polymorphisms, the $-521 \mathrm{C}>\mathrm{T}$ SNP has been widely studied since it was shown to be associated with the personality trait of novelty seeking $[16,34]$. Frequency data obtained for the $-521 \mathrm{C}>\mathrm{T}$ SNP seem to be considerably constant among the populations (see Tab. 2), as frequency differences between the ethnic groups are smaller than the variations observed within the same study group. Therefore, the alterations in the frequency between the $\mathrm{C}$ vs. T alleles can be readily explained by the differences in methodology and sample size. One of the possible sources of technical difficulties might originate from using the PCR-RFLP protocol designed by Okuyama et al. [32], where the 3' end of the reverse primer anneals to the polymorphic $-603^{\text {rd }}$ position [41], $-603 \mathrm{~T}>\mathrm{del}$ ), which might result in unequal amplification of the homologous chromosomes in heterozygotes. Therefore the position of the primers were changed in other protocols, including the previously described PCR-RFLP system, where an internal control restriction site was added to the system [16]. In order to enhance the validity and reliability, two parallel methods were used for genotyping the -521C > T SNP in our laboratory, a PCR-RFLP and a fast allele-specific protocol [56]. Using a large sample $(\mathrm{N}=$ $598)$, we found a somewhat lower $(46.5 \%)$ allele frequency for the $-521 \mathrm{C}$ allele compared to the $-521 \mathrm{~T}$ allele and the genotype frequencies corresponded to the HardyWeinberg equilibrium (see Table 2., line 1). 
Table 2: Genotypes and allele frequencies of the -52I CT SNP in different populations

\begin{tabular}{|c|c|c|c|c|c|c|c|c|}
\hline \multicolumn{2}{|r|}{ Origin of population } & \multicolumn{3}{|c|}{ Allele frequency (\%) } & \multicolumn{4}{|c|}{ Genotype frequency (\%) } \\
\hline & & $2 \mathbf{N}$ & C & $\mathbf{T}$ & $\mathbf{N}$ & CC & $\mathbf{C T}$ & TT \\
\hline \multirow[t]{6}{*}{ Caucasian } & Hungarian (Szantai et al., 2005) & 1196 & 46.5 & 53.5 & 598 & 21.4 & 50.0 & 28.6 \\
\hline & European-mixed (Barr et al., 200I) & 308 & 45.8 & 54.2 & 154 & & & \\
\hline & German (Strobel et al., 2003) & 230 & 40.0 & 60.0 & 115 & 20.9 & 38.3 & 40.8 \\
\hline & Swedish (Jönsson et al., 200I) & 776 & 42.0 & 58.0 & 388 & 15.0 & 54.0 & 31.0 \\
\hline & mean & & 44.4 & 55.6 & & 19.1 & 50.2 & 30.7 \\
\hline & Standard deviation & & 2.4 & 2.4 & & 3.0 & 4.5 & 3.6 \\
\hline \multirow[t]{9}{*}{ Asian } & Japanese (Okuyama et al., 1999) & 538 & 41.0 & 59.0 & 269 & 14.0 & 53.0 & 33.0 \\
\hline & Japanese (Ishiguro et al., 2000) & 538 & 41.0 & 60.0 & 269 & 14.0 & 53.0 & 33.0 \\
\hline & Japanese (Mitsuyasu et al., 1999) & 294 & 41.0 & 59.0 & 147 & 17.9 & 46.3 & 35.8 \\
\hline & Japanese (Okuyama et al., 2000) & 172 & 53.5 & 46.5 & 86 & 32.5 & 41.9 & 25.6 \\
\hline & Chinese (Xing et al., 2003) & 412 & 39.1 & 60.9 & 206 & 12.1 & 53.9 & 34.0 \\
\hline & Chinese (Li et al., 2000) & 422 & 40.3 & 59.7 & 211 & 27.5 & 25.6 & 46.9 \\
\hline & Korean (Lee et al., 2003) & 202 & 46.0 & 54.0 & 101 & & & \\
\hline & mean & & 41.8 & 58.4 & & 17.9 & 46.7 & 35.5 \\
\hline & Standard deviation & & 3.5 & 3.6 & & 6.7 & 10.4 & 5.8 \\
\hline American & Afro-American (Bookman et al., 2002) & 142 & 55.0 & 45.0 & 71 & 32.0 & 42.0 & 26.0 \\
\hline
\end{tabular}

Although the literature of the $-616 \mathrm{C}>\mathrm{G}$ SNP is limited, the available genotype frequencies do vary among different ethnic groups significantly as shown in Tab. (3). The frequency of the two alleles were quite similar $(-616 \mathrm{C}$ : 51.5\%,-616G: 48.5\%) in the Hungarian population studied, whereas in Asian and Afro-American populations a higher occurrence of the $-616 \mathrm{G}$ allele $(69.7 \%$ and $71.8 \%$ respectively) was observed. It is difficult to account for the significant difference between the mixed-European and the Hungarian samples. According to our recent results [30], the Ava II RFLP genotyping protocol [29] overestimated the $-616 \mathrm{C}$ allele in the presence of the $-615 \mathrm{G}$ allele of a novel SNP in this position. Sau96 I, in place of the Ava II restriction enzyme, was shown to be the appropriate choice of restriction endonuclease [30], as the newly described $-615 \mathrm{~A}>\mathrm{G}$ SNP had no influence on the digestion reaction by Sau96 I. This is another example of how obtained allele frequencies depend on differences in methodology, providing a source of unreplicated association studies.

Recently, significant amount of interest has been focused on a polymorphic tandem repeat element located $1.2 \mathrm{~kb}$ upstream of the initiation codon in the DRD4 promoter. The $120 \mathrm{bp}$ of duplicated sequence was linked to ADHD and might be involved in the regulation of transcription $[43,57]$. Allele frequency variation is high among populations, in Europeans the duplicated form is more common than in other populations (see Tab. 4). Since the region of this length variation is not GC rich and it is further away from the polymorphic hotspot of the DRD4 promoter, no significant genotyping obstacles have been found.

Fig. (4) summarizes the polymorphisms highlighted by the literature, and the number of the variants keeps increasing. Some of the recently described polymorphisms such as the $-1106 \mathrm{C}>\mathrm{T},-906 \mathrm{C}>\mathrm{T}$ [27], $-615 \mathrm{~A}>\mathrm{G}$ [30] SNPs and the novel 27 bp deletion, described here have not been characterized yet more thoroughly. The 27 bp deletion can be rapidly genotyped with the assay described in this paper and could be a component of further association studies that analyze the $5^{\prime}$ region of the DRD4 gene. Additionally, the dbSNP database of the NCBI contains numerous further SNPs in the non-coding region of the gene $(-872 A>G,-844 C>G,-764 A>C$, $754 \mathrm{C}>\mathrm{G},-713 \mathrm{C}>\mathrm{G},-599 \mathrm{C}>\mathrm{G},-528 \mathrm{C}>\mathrm{T},-364 \mathrm{~A}>\mathrm{G})$ that haven't even been published yet. Theoretical approaches have shown that highly variable polymorphic markers are more useful in association analysis than less polymorphic ones, since there is a higher probability to identify allele frequency differences between cases and controls [58]. Similarly, analysis of haplotypes, involving several polymorphic sites, might provide a greater power for association analysis. Haplotypes of the $120 \mathrm{bp}$ duplication [31] and some of the SNPs $[23,29]$ published earlier have already been the targets of numerous genetic association 
Table 3: Allele and genotype frequencies of the -616 CG SNP in 5 populations

\begin{tabular}{|c|c|c|c|c|c|c|c|c|}
\hline \multicolumn{2}{|r|}{ Origin of population } & \multicolumn{3}{|c|}{ Allele frequency (\%) } & \multicolumn{4}{|c|}{ Genotype frequency (\%) } \\
\hline & & $2 \mathbf{N}$ & C & $\mathbf{G}$ & $\mathbf{N}$ & CC & CG & GG \\
\hline \multirow[t]{4}{*}{ Caucasian } & Hungarian (Szantai et al., 2005) & 1196 & 51.5 & 48.5 & 598 & 27.8 & 47.5 & 24.7 \\
\hline & European-mixed (Barr et al., 200I) & 308 & 72.7 & 27.3 & 154 & & & \\
\hline & mean & & 55.8 & 44.2 & & $31.1 *$ & 49.3* & 19.5* \\
\hline & Standard deviation & & 8.6 & 8.6 & & & & \\
\hline \multirow[t]{4}{*}{ Asian } & Japanese (Mitsuyasu et al., 1999) & 160 & 28.4 & 71.6 & 80 & 14.9 & 26.9 & 58.2 \\
\hline & Chinese (Xing et al., 2003) & 412 & 31.1 & 68.9 & 206 & 6.3 & 49.5 & 44.2 \\
\hline & mean & & 30.3 & 69.7 & & 8.7 & 43.2 & 48.1 \\
\hline & Standard deviation & & 1.2 & 1.2 & & 3.9 & 10.1 & 6.3 \\
\hline American & Afro-American (Bookman et al., 2002) & 142 & 28.2 & 71.8 & 71 & 13.0 & 31.0 & 56.0 \\
\hline
\end{tabular}

* Expected genotype frequencies were calculated from measured allele frequencies assuming Hardy-Weinberg equilibrium in the populations.

Table 4: Frequency distribution for the 120 bp duplicated alleles of the DRD4 promoter

\begin{tabular}{|c|c|c|c|c|c|c|c|c|}
\hline \multicolumn{2}{|r|}{ Origin of population } & \multicolumn{3}{|c|}{ Allele frequency (\%) } & \multicolumn{4}{|c|}{ Genotype frequency (\%) } \\
\hline & & $2 \mathbf{N}$ & $\mathbf{I}$ & 2 & $\mathbf{N}$ & $1 / 1$ & $1 / 2$ & $2 / 2$ \\
\hline \multirow[t]{5}{*}{ Caucasian } & Hungarian (Szantai et al., 2005) & 1196 & 17.1 & 82.9 & 598 & 3.0 & 28.3 & 68.7 \\
\hline & European-mixed (Seaman et al., 1999) & 174 & 19.5 & 80.5 & & & & \\
\hline & European-mixed (Barr et al., 200I) & 308 & 19.9 & 80.1 & & & & \\
\hline & mean & & 17.9 & 82.1 & & $3.2 *$ & $29.4^{*}$ & 67.4* \\
\hline & Standard deviation & & 1.5 & 1.5 & & & & \\
\hline \multirow[t]{4}{*}{ Asian } & Chinese (Xing et al., 2003) & 412 & 37.4 & 62.6 & 206 & 13.6 & 47.6 & 38.8 \\
\hline & Chinese (Seaman et al., 1999) & 122 & 36.1 & 63.9 & & & & \\
\hline & mean & & 37.1 & 62.9 & & $13.8 *$ & $46.6 *$ & $39.6 *$ \\
\hline & Standard deviation & & 0.5 & 0.5 & & & & \\
\hline African & African (Seaman et al., 1999) & 136 & 59.6 & 40.4 & & $35.5^{*}$ & $48.2^{*}$ & $16.3^{*}$ \\
\hline American & Mayan (Seaman et al., 1999) & 106 & 48.1 & 51.9 & & $23.1 *$ & $49.9 *$ & $26.9^{*}$ \\
\hline
\end{tabular}

* Expected genotype frequencies were calculated from measured allele frequencies assuming Hardy-Weinberg equilibrium in the populations.

studies. Recently, direct haplotype detection methods for the commonly investigated $-521 \mathrm{C}>\mathrm{T}$ and $-616 \mathrm{C}>\mathrm{G}$ SNPs as well as the $120 \mathrm{bp}$ duplication promoter polymorphisms were developed in our laboratory $[59,60]$. Linkage disequilibrium analysis of polymorphisms marks the different haplotype blocks on the chromosome segment giving way to future association studies [61].
The polymorphic variations in the regulatory region may directly influence the regulation of transcription of the DRD4 gene. It was demonstrated that some of these polymorphisms have functional effects resulting in different transcriptional activity $[32,57]$. Furthermore, the $120 \mathrm{bp}$ duplication and the $\mathrm{C}$ to $\mathrm{G}$ change at the $-616^{\text {th }}$ position cause the gain of additional binding sites of known tran- 
scription elements $[31,39,62]$. Accordingly, we examined the deleted sequence for any potential transcriptional binding sites and found the consensus sequences of several factors, including $S p 1, A P-2 a l p h a B$ and NF-E2. It has been reported in a human retinoblastoma cell line that the $-521 \mathrm{C}>\mathrm{T}$ SNP has significant influence on the transcriptional efficiency of the DRD4 gene suggesting the relevance of a single SNP in dopaminergic neurotransmission [32]. As the 27 bp deletion lies in the very same region, it can be assumed that this variation might also have a considerable impact on the transcriptional activity of the gene.

\section{Methods}

\section{Participants}

DNA was extracted from epithelial cells of 959 healthy subjects (396 male and 563 female) in a Caucasian sample of Hungarian origin. Signed informed consent was obtained from all the participants. The research protocol was approved by the Research Ethics Committee.

\section{Non-invasive DNA sampling}

Buccal cells were collected by cotton swabs from the inner surface of the mouth [63]. DNA was isolated by phenol extraction and alcohol precipitation as described earlier [64].

\section{Genotyping protocol for the $27 \mathrm{bp}$ del}

The Qiagen ${ }^{\circledast}$ HotStarTaq $^{\mathrm{TM}}$ DNA polymerase kit was used for polymerase chain reaction (PCR). Reaction mixtures contained $200 \mu \mathrm{M}$ dATP, dCTP, dTTP, and $100 \mu \mathrm{M}$ dGTP and dITP; $1 \mu \mathrm{M}$ of forward primer (5'-GGA ATG GAG GAG GGA GCG GG-3'), and $1 \mu \mathrm{M}$ of reverse primer (5'GAC GCC AGC GCC ATC CTA CC-3'), approximately 1 ng DNA template, $0.25 \mathrm{U}$ DNA polymerase, $1 \mathrm{x}$ reaction buffer, and $1 \times$ Q solution in a total volume of $10 \mu \mathrm{L}$. Thermocycling was initiated at $95^{\circ} \mathrm{C}$ for 15 minutes to activate the hot start enzyme and to denature genomic DNA, which was followed by 35 cycles of 1 min denaturation at $94^{\circ} \mathrm{C}, 30 \mathrm{sec}$ annealing at $65^{\circ} \mathrm{C}$ and $1 \mathrm{~min}$ extension at $72^{\circ} \mathrm{C}$. A final $10 \mathrm{~min}$ extension step at $72^{\circ} \mathrm{C}$ was followed by cooling the samples to $8^{\circ} \mathrm{C}$. PCR products were analyzed by conventional submarine horizontal agarose gelelectrophoresis (MidiGel of Biocenter, Szeged, Hungary). A composite gel was applied containing 1.5\% low EEO agarose Type I (Sigma Chemicals) and 2\% Methaphor agarose "fine resolution" (Cambrex Corporation). Separation was performed at room temperature in $40 \mathrm{mM}$ Tris, 10 mM EDTA. $\mathrm{Na}_{2}, 1 \%$ acetic acid (pH 8.0) buffer and 6.6 $\mathrm{V} / \mathrm{cm}$ (100 V field strength, $26 \mathrm{~mA}$ ) for $90 \mathrm{~min}$. After separation, dsDNA fragments were stained in $1 \mu \mathrm{g} / \mathrm{mL}$ ethidium bromide solution at room temperature for 15 minutes. No destaining was necessary. A BioRad Gel-Doc 1000 gel-documentation system (Hercules) was used for visualization of the DNA fragments.

\section{DNA sequencing}

Genomic DNA of individuals shown to carry the deleted allele were sequenced by amplification of the region in question using the above described PCR conditions. Polymerase chain reaction was carried out by the forward primer: 5'-GGA ATG GAG GAG GGA GCG GG-3', and reverse primer: 5'-CGC TCC ACC GTG AGC CCA GTA T3'. The shorter PCR product (deleted allele) was purified from the gel using the Qiagen QIAquick Spin DNA-Extraction Kit. DNA sequencing was performed by an ABI 370 Sequencer, using the reverse primer (see above) of the amplification reaction.

\section{Database searching}

The 27 bp of sequence, which is deleted in the mutant allele, was searched for known transcription factor binding sites using the Transcription Element Search Software (TESS) web-based search tool to search the TransFac database; http://www.cbil.upenn.edu/tess [65].

\section{Authors' contributions}

ES carried out the genotyping experiments of the 959 individuals, took part in the elaboration of the novel genotyping procedure and helped to draft the manuscript. RS analyzed the results of the initial experiments suggesting the presence of the novel mutation and drafted the manuscript. MS conceived of the study and participated in its design and coordination. AG carried out the database search and coordinated the experimental work. ZR designed the primers for the investigation of the $27 \mathrm{bp}$ del and optimized the genotyping protocol, analyzed the sequencing results and helped to finalize the manuscript. All authors read and approved the final manuscript.

\section{Acknowledgements}

We are grateful to O. Kiraly, M. Szoke and Z. Csapo for valuable discussions and help with sequencing the deleted allele, and to G. Kolmann for her technical assistance. This work was supported by Hungarian grants NKFP 0008/2002, GVOP AKF 3I I 2004050324 3.0 and OTKA F42730. E. Szantai is indebted to L. Orosz, the head of her Ph.D. Program (Classical and Molecular Genetics) at Eötvös Loránd University, Budapest.

\section{References}

I. Jaber M, Robinson SW, Missale C, Caron MG: Dopamine receptors and brain function. Neuropharmacology 1996, 35:1503-1519.

2. Oak JN, Oldenhof J, Van Tol HH: The dopamine $\mathbf{D}(4)$ receptor: one decade of research. Eur J Pharmacol 2000, 405:303-327.

3. Gelernter J, Kennedy JL, Van Tol HH, Civelli O, Kidd KK: The D4 dopamine receptor (DRD4) maps to distal I Ip close to HRAS. Genomics 1992, I 3:208-210.

4. Petronis A, Van Tol HH, Lichter JB, Livak KJ, Kennedy JL: The D4 dopamine receptor gene maps on IIp proximal to HRAS. Genomics 1993, 18:161-163.

5. Catalano M, Nobile M, Novelli E, Nothen MM, Smeraldi E: Distribution of a novel mutation in the first exon of the human dopamine D4 receptor gene in psychotic patients. Biol Psychiatry 1993, 34:459-464.

6. Faraone SV, Doyle AE, Mick E, Biederman J: Meta-analysis of the association between the 7-repeat allele of the dopamine D(4) receptor gene and attention deficit hyperactivity disorder. Am J Psychiatry 200I, I 58: I052-I057. 
7. Grice DE, Leckman JF, Pauls DL, Kurlan R, Kidd KK, Pakstis AJ, Chang FM, Buxbaum JD, Cohen DJ, Gelernter J: Linkage disequilibrium between an allele at the dopamine D4 receptor locus and Tourette syndrome, by the transmission-disequilibrium test. Am J Hum Genet 1996, 59:644-652.

8. LaHoste GJ, Swanson JM, Wigal SB, Glabe C, Wigal T, King N, Kennedy JL: Dopamine D4 receptor gene polymorphism is associated with attention deficit hyperactivity disorder. Mol Psychiatry 1996, I: I2I-I 24.

9. Comings DE, Gonzalez N, Wu S, Gade R, Muhleman D, Saucier G, Johnson P, Verde R, Rosenthal RJ, Lesieur HR, Rugle LJ, Miller WB, MacMurray JP: Studies of the 48 bp repeat polymorphism of the DRD4 gene in impulsive, compulsive, addictive behaviors: Tourette syndrome, ADHD, pathological gambling, and substance abuse. Am J Med Genet 1999, 88:358-368.

10. Kotler M, Cohen H, Segman R, Gritsenko I, Nemanov L, Lerer B, Kramer I, Zer-Zion M, Kletz I, Ebstein RP: Excess dopamine D4 receptor (D4DR) exon III seven repeat allele in opioiddependent subjects. Mol Psychiatry 1997, 2:25I-254.

II. Muramatsu T, Higuchi S, Murayama M, Matsushita S, Hayashida M: Association between alcoholism and the dopamine D4 receptor gene. J Med Genet 1996, 33: I I3-I I5.

12. Benjamin J, Li L, Patterson C, Greenberg BD, Murphy DL, Hamer DH: Population and familial association between the D4 dopamine receptor gene and measures of Novelty Seeking. Nat Genet 1996, 12:81-84.

13. Ebstein RP, Novick O, Umansky R, Priel B, Osher Y, Blaine D, Bennett ER, Nemanov L, Katz M, Belmaker RH: Dopamine D4 receptor (D4DR) exon III polymorphism associated with the human personality trait of Novelty Seeking. Nat Genet 1996, I 2:78-80.

14. Noble EP, Ozkaragoz TZ, Ritchie TL, Zhang X, Belin TR, Sparkes RS: D2 and D4 dopamine receptor polymorphisms and personality. Am J Med Genet 1998, 8I:257-267.

15. Rogers G, Joyce P, Mulder R, Sellman D, Miller A, Allington M, Olds $R$, Wells E, Kennedy M: Association of a duplicated repeat polymorphism in the 5 -untranslated region of the DRD4 gene with novelty seeking. Am J Med Genet 2004, I 26B:95-98.

16. Ronai Z, Szekely A, Nemoda Z, Lakatos K, Gervai J, Staub M, SasvariSzekely M: Association between Novelty Seeking and the -52I $C / T$ polymorphism in the promoter region of the DRD4 gene. Mol Psychiatry 200I, 6:35-38.

17. Ebstein RP, Benjamin J, Belmaker RH: Personality and polymorphisms of genes involved in aminergic neurotransmission. Eur J Pharmacol 2000, 410:205-2। 4

18. Kennedy JL, Sidenberg DG, Van Tol HH, Kidd KK: A Hincll RFLP in the human D4 dopamine receptor locus (DRD4). Nucleic Acids Res 1991, 19:5801.

19. Van Tol HH, Wu CM, Guan HC, Ohara K, Bunzow JR, Civelli O, Kennedy J, Seeman P, Niznik HB, Jovanovic V: Multiple dopamine D4 receptor variants in the human population. Nature 1992, 358: $149-152$.

20. Asghari V, Sanyal S, Buchwaldt S, Paterson A, Jovanovic V, Van Tol $\mathrm{HH}$ : Modulation of intracellular cyclic AMP levels by different human dopamine D4 receptor variants. J Neurochem 1995, 65: II57-1165.

21. Kluger AN, Siegfried Z, Ebstein RP: A meta-analysis of the association between DRD4 polymorphism and novelty seeking. Mol Psychiatry 2002, 7:7 12-7|7.

22. Cichon S, Nothen MM, Catalano M, Di Bella D, Maier W, Lichtermann $D$, Minges J, Albus M, Borrmann M, Franzek E, .: Identification of two novel polymorphisms and a rare deletion variant in the human dopamine D4 receptor gene. Psychiatr Genet 1995, 5:97-103.

23. Nothen MM, Cichon S, Hemmer S, Hebebrand J, Remschmidt H, Lehmkuhl G, Poustka F, Schmidt M, Catalano M, Fimmers R, .: Human dopamine D4 receptor gene: frequent occurrence of a null allele and observation of homozygosity. Hum Mol Genet 1994 3:2207-2212.

24. Seeman P, Ulpian C, Chouinard G, Van Tol HH, Dwosh H, Lieberman JA, Siminovitch K, Liu IS, Waye J, Voruganti P, .: Dopamine D4 receptor variant, D4GLYCINEI94, in Africans, but not in Caucasians: no association with schizophrenia. Am J Med Genet 1994, 54:384-390.

25. Barr CL, Kennedy JL, Lichter JB, Van Tol HH, Wetterberg L, Livak KJ, Kidd KK: Alleles at the dopamine D4 receptor locus do not contribute to the genetic susceptibility to schizophrenia in a large Swedish kindred. Am J Med Genet 1993, 48:218-222.

26. Shimada MK, Inoue-Murayama M, Ueda Y, Maejima M, Murayama $Y$, Takenaka O, Hayasaka I, Ito S: Polymorphism in the second intron of dopamine receptor D4 gene in humans and apes. Biochem Biophys Res Commun 2004, 3 I6: I 186-1 I 90.

27. Wang E, Ding YC, Flodman P, Kidd JR, Kidd KK, Grady DL, Ryder OA, Spence MA, Swanson JM, Moyzis RK: The Genetic Architecture of Selection at the Human Dopamine Receptor D4 (DRD4) Gene Locus. Am J Hum Genet 2004, 74:.

28. Kamakura S, Iwaki A, Matsumoto M, Fukumaki Y: Cloning and characterization of the 5 '-flanking region of the human dopamine D4 receptor gene. Biochem Biophys Res Commun 1997, 235:32I-326.

29. Mitsuyasu H, Ozawa H, Takeda Y, Fukumaki Y: Novel polymorphisms in the upstream region of the human dopamine D4 receptor (DRD4) gene. J Hum Genet 1999, 44:416-418.

30. Ronai Z, Szantai E, Szmola R, Nemoda Z, Szekely A, Gervai ], Guttman A, Sasvari-Szekely M: A novel A/G SNP in the $-6 / 5$ th position of the dopamine D4 receptor promoter region as a source of misgenotyping of the -616 C/G SNP. Am J Med Genet 2004, I 26B:74-78.

31. Seaman MI, Fisher JB, Chang F, Kidd KK: Tandem duplication polymorphism upstream of the dopamine D4 receptor gene (DRD4). Am J Med Genet 1999, 88:705-709.

32. Okuyama $Y$, Ishiguro $H$, Toru $M$, Arinami T: A genetic polymorphism in the promoter region of DRD4 associated with expression and schizophrenia. Biochem Biophys Res Commun 1999, 258:292-295.

33. Bookman EB, Taylor RE, Adams-Campbell L, Kittles RA: DRD4 promoter SNPs and gender effects on Extraversion in African Americans. Mol Psychiatry 2002, 7:786-789.

34. Okuyama $Y$, Ishiguro $H$, Nankai $M$, Shibuya $H$, Watanabe A, Arinami $\mathrm{T}$ : Identification of a polymorphism in the promoter region of DRD4 associated with the human novelty seeking personality trait. Mol Psychiatry 2000, 5:64-69.

35. Ekelund J, Suhonen J, Jarvelin MR, Peltonen L, Lichtermann D: No association of the $-521 \mathrm{C} / \mathrm{T}$ polymorphism in the promoter of DRD4 with novelty seeking. Mol Psychiatry 200I, 6:618-619.

36. Jonsson EG, Ivo R, Gustavsson JP, Geijer T, Forslund K, MattilaEvenden M, Rylander G, Cichon S, Propping P, Bergman H, sberg M, Nothen MM: No association between dopamine D4 receptor gene variants and novelty seeking. Mol Psychiatry 2002, 7:18-20.

37. Strobel A, Lesch KP, Hohenberger K, Jatzke S, Gutzeit HO, Anacker $\mathrm{K}$, Brocke B: No association between dopamine D4 receptor gene exon III and $-521 \mathrm{C} / \mathrm{T}$ polymorphism and novelty seeking. Mol Psychiatry 2002, 7:537-538.

38. Schinka JA, Letsch EA, Crawford FC: DRD4 and novelty seeking: results of meta-analyses. Am J Med Genet 2002, I I 4:643-648.

39. Barr CL, Feng Y, Wigg KG, Schachar R, Tannock R, Roberts W, Malone M, Kennedy JL: 5'-untranslated region of the dopamine D4 receptor gene and attention-deficit hyperactivity disorder. Am J Med Genet 200I, I 05:84-90

40. Lowe N, Kirley A, Mullins C, Fitzgerald M, Gill M, Hawi Z: Multiple marker analysis at the promoter region of the DRD4 gene and ADHD: Evidence of linkage and association with the SNP -6 I 6. Am J Med Genet 2004, I 3 I B:33-37.

41. Mitsuyasu H, Hirata N, Sakai $Y$, Shibata H, Takeda $Y$, Ninomiya $H$, Kawasaki $\mathrm{H}$, Tashiro N, Fukumaki Y: Association analysis of polymorphisms in the upstream region of the human dopamine D4 receptor gene (DRD4) with schizophrenia and personality traits. J Hum Genet 200I, 46:26-3I.

42. Paterson AD, Ying DJ, Petronis A, Schoots O, Lieberman JA, Van Tol $\mathrm{HH}$, Kennedy JL: A Pstl restriction fragment length polymorphism in the 5' untranslated region of DRD4 is not associated with schizophrenia. Psychiatr Genet 1996, 6:191-193.

43. McCracken JT, Smalley SL, McGough J], Crawford L, Del'Homme M, Cantor RM, Liu A, Nelson SF: Evidence for linkage of a tandem duplication polymorphism upstream of the dopamine D4 receptor gene (DRD4) with attention deficit hyperactivity disorder (ADHD). Mol Psychiatry 2000, 5:53I-536.

44. Ronai Z, Guttman A, Keszler G, Sasvari-Szekely M: Capillary electrophoresis study on DNA-protein complex formation in the polymorphic 5' upstream region of the dopamine D4 receptor (DRD4) gene. Curr Med Chem 2004, I I: I023-I029. 
45. Seeman P, Guan HC, Van Tol HH: Dopamine D4 receptors elevated in schizophrenia. Nature 1993, 365:44I-445.

46. Seeman P, Guan HC, Nobrega J, Jiwa D, Markstein R, Balk JH, Picetti $\mathrm{R}$, Borrelli E, Van Tol HH: Dopamine D2-like sites in schizophrenia, but not in Alzheimer's, Huntington's, or control brains, for [3H]benzquinoline. Synapse 1997, 25:| 37-| 46.

47. Stefanis NC, Bresnick JN, Kerwin RW, Schofield WN, McAllister G: Elevation of D4 dopamine receptor mRNA in postmortem schizophrenic brain. Brain Res Mol Brain Res 1998, 53: I I 2-I I 9.

48. Hwang CK, D'Souza UM, Eisch AJ, Yajima S, Lammers CH, Yang Y, Lee SH, Kim YM, Nestler EJ, Mouradian MM: Dopamine receptor regulating factor, DRRF: a zinc finger transcription factor. Proc Natl Acad Sci U S A 200I, 98:7558-7563.

49. Chang FM, Kidd JR, Livak KJ, Pakstis AJ, Kidd KK: The world-wide distribution of allele frequencies at the human dopamine D4 receptor locus. Hum Genet 1996, 98:91-10I.

50. Mill JS, Caspi A, McClay J, Sugden K, Purcell S, Asherson P, Craig I, McGuffin P, Braithwaite A, Poulton R, Moffitt TE: The dopamine D4 receptor and the hyperactivity phenotype: a developmental-epidemiological study. Mol Psychiatry 2002, 7:383-39I.

5I. Strobel A, Lesch KP, Jatzke S, Paetzold F, Brocke B: Further evidence for a modulation of Novelty Seeking by DRD4 exon III, 5-HTTLPR, and COMT val/met variants. Mol Psychiatry 2003, 8:37I-372.

52. Ronai Z, Guttman A, Nemoda Z, Staub M, Kalasz H, Sasvari-Szekely $M$ : Rapid and sensitive genotyping of dopamine $D 4$ receptor tandem repeats by automated ultrathin-layer gel electrophoresis. Electrophoresis 2000, 21:2058-206I.

53. Ding YC, Chi HC, Grady DL, Morishima A, Kidd JR, Kidd KK, Flodman P, Spence MA, Schuck S, Swanson JM, Zhang YP, Moyzis RK: Evidence of positive selection acting at the human dopamine receptor D4 gene locus. Proc Natl Acad Sci U S A 2002, 99:309-3I4.

54. Chen CS, Burton M, Greenberger E, Dmitrieva J: Population migration and the variation of dopamine D4 receptor (DRD4) allele frequencies around the globe. Evolution and Human Behavior 1999, 20:309-324.

55. Hamer D, Sirota L: Beware the chopsticks gene. Mol Psychiatry 2000, 5: II-13.

56. Ronai Z, Barta C, Guttman A, Lakatos K, Gervai J, Staub M, SasvariSzekely M: Genotyping the -52 I C/T functional polymorphism in the promoter region of dopamine D4 receptor (DRD4) gene. Electrophoresis 2001, 22:1 I02-II05.

57. D'Souza UM, Russ C, Tahir E, Mill J, McGuffin P, Asherson PJ, Craig IW: Functional effects of a tandem duplication polymorphism in the 5'flanking region of the DRD4 gene. Biol Psychiatry 2004, 56:69I-697.

58. Sham PC, Zhao JH, Waldman I, Curtis D: Should ambiguous trios for the TDT be discarded? Ann Hum Genet 2000, 64:575-576.

59. Ronai Z, Guttman A, Nemoda Z, Gervai J, Sasvari-Szekely M: Direct haplotype detection of adjacent polymorphic sites in the regulatory region of the dopamine D4 receptor (DRD4) gene. Electrophoresis 2002, 23:15I2-1516.

60. Szantai E, Kiraly O, Nemoda Z, Kereszturi E, Csapo Z, Sasvari-Szekely M, Gervai J, Ronai Z: Linkage analysis and molecular haplotyping of the dopamine D4 receptor gene promoter region. Psychiatr Genet 2005, in press:

6I. Lai E, Bowman C, Bansal A, Hughes A, Mosteller M, Roses AD: Medical applications of haplotype-based SNP maps: learning to walk before we run. Nat Genet 2002, 32:353.

62. Williams T, Tjian R: Analysis of the DNA-binding and activation properties of the human transcription factor AP-2. Genes Dev 1991, 5:670-682

63. Meulenbelt I, Droog S, Trommelen GJ, Boomsma DI, Slagboom PE: High-yield noninvasive human genomic DNA isolation method for genetic studies in geographically dispersed families and populations. Am J Hum Genet 1995, 57:1252-I254.

64. Sambrook J, Fritsch EF, Maniatis T: Molecular cloning: A Laboratory Manual, 2nd Ed.,. New York, Cold Spring Harbor Laboratory, Cold Spring Harbor; 2005.

65. Schug J, Overton GC: Modeling transcription factor binding sites with Gibbs Sampling and Minimum Description Length encoding. Proc Int Conf Intell Syst Mol Biol 1997, 5:268-27I.
Publish with Bio Med Central and every scientist can read your work free of charge

"BioMed Central will be the most significant development for disseminating the results of biomedical research in our lifetime. "

Sir Paul Nurse, Cancer Research UK

Your research papers will be:

- available free of charge to the entire biomedical community

- peer reviewed and published immediately upon acceptance

- cited in PubMed and archived on PubMed Central

- yours - you keep the copyright
BioMedcentral 